\title{
Ophiotaenia bonneti sp. n. (Eucestoda: Proteocephalidea), a parasite of Rana vaillanti (Anura: Ranidae) in Costa Rica
}

\author{
Alain de Chambrier ${ }^{1}$, Sandrine C. Coquille ${ }^{1}$ and Daniel R. Brooks ${ }^{2}$ \\ ${ }^{1}$ Muséum d'histoire naturelle, P.O. Box 6434, CH-1211 Geneva 6, Switzerland; \\ ${ }^{2}$ Department of Zoology, University of Toronto, 25 Harbord Street, Toronto, ON M5S 3G5, Canada
}

Key words: Eucestoda, Proteocephalidea, Ophiotaenia bonneti, Rana vaillanti, Costa Rica, specificity

\begin{abstract}
Ophiotaenia bonneti sp. n. is described from the intestine of the frog Rana vaillanti Brocchi, 1877 (Anura: Ranidae) from San Gerardo, Guanacaste, Costa Rica. The new species is characterized by the testes 100-177 in number, the genital pores situated anteriorly, the osmoregulatory canals overlapping the testis field, the cirrus pouch length as $15-24 \%$ of proglottis width, and the uterus with 18-32 ramified diverticula on each side. It differs from the 23 known species of the genus Ophiotaenia La Rue, 1911, parasitic in amphibians, by one to several morphological characters. It differs from $O$. gracilis Jones, Cheng et Gillespie, 1958, the most morphologically similar species, in the sucker diameter in $\%$ of scolex diameter and in the morphology of the eggs - funnel-like depression and embryophore closely investing the oncosphere in $O$. gracilis. We generally observe a very low mean prevalence of the Proteocephalidea in Neotropical amphibians (about $0.41 \%-3 \%$ ), but in the case of some host species, the prevalence can reach up to $25 \%$. We conclude that these cestodes exhibit a strict host specificity of the oioxene type. Ophiotaenia junglensis Srivastava et Capoor, 1980 is considered a species inquirenda. Batrachotaenia hernandezi (Flores-Barroeta, 1955) becomes Ophiotaenia hernandezi (Flores-Barroeta, 1955) comb. n., B. tigrina (Woodland, 1925) becomes O. tigrina (Woodland, 1925) comb. n. and B. ceratophryos (Parodi et Widakowich, 1916) becomes O. ceratophryos (Parodi et Widakowich, 1916) comb. n.
\end{abstract}

As a part of its mandate to develop and manage sustainably Costa Rica's biodiversity resources, the Area de Conservación Guanacaste (ACG) has approved a long-term project called "Inventory of the Eukaryotic Parasites of Vertebrates of the Area de Conservación Guanacaste". This is an effort to document all species of eukaryotic parasites inhabiting the estimated 940 species of vertebrates with populations living within the boundaries of the ACG.

In the framework of this project, 147 Rana vaillanti Brocchi, 1877 were examined for parasites between 1999 and 2002. Among them, 33 Rana vaillanti (22\%) were found to harbour tapeworms belonging to the Proteocephalidea. In the Central American region, only one species of proteocephalidean, Batrachotaenia hernandezi (Flores-Barroeta, 1955), has previously been described from an amphibian, Rana sp., in Mexico (Flores-Barroeta 1955). The characteristics of the Costa Rican material led us to describe a new species of Ophiotaenia La Rue, 1911 in the present paper.

\section{MATERIALS AND METHODS}

The cestode specimens were fixed directly after dissection of the host's intestine in AFA solution and subsequently stored in $75 \%(\mathrm{v} / \mathrm{v})$ ethanol. They were stained with Mayer's hydrochloric carmine solution or Weigert's haematoxylin, dehydrated in ethanol, cleared with Eugenol (clove oil) and mounted in Canada balsam. Pieces of strobila were embedded in paraffin wax, sectioned transversely at $12 \mu \mathrm{m}$, stained with
Weigert's haematoxylin and counterstained with $1 \%$ eosin B (acidified with five drops of pure acetic acid for $100 \mathrm{ml}$ solution) following recently updated protocols (Scholz and Hanzelová 1998, de Chambrier 2001).

Three specimens were prepared for scanning electron microscopy (SEM) as follows: specimens were dehydrated in graded ethanol series, then transferred to graded amyl acetate series, critical point dried in $\mathrm{CO}_{2}$, sputtered with gold and examined with a Zeiss DSM 940 A electron microscope at the Museum of Natural History, Geneva. Eggs were studied in distilled water. Microtrix terminology follows Thompson et al. (1980) and Hoberg et al. (1995). All measurements are given in micrometres unless otherwise indicated. Abbreviations used in descriptions are as follows: $\times-$ mean; $\mathrm{n}$ - number of measurements; OV - ovarian width as \% of proglottis width; PP position of genital pore as $\%$ of proglottis length from anterior end; $\mathrm{PC}$ - cirrus pouch length as \% of proglottis width; CV coefficient of variation. Museum abbreviations used are as follows: MHNG: Geneva Natural History Museum, Invertebrate Collection (INVE), Geneva, Switzerland; IPCAS: Institute of Parasitology, ASCR, České Budějovice, Czech Republic; USNPC: U.S. National Parasite Collection, Beltsville, USA. Names of amphibian hosts follow Frost 2004.

\section{RESULTS \\ Ophiotaenia bonneti sp. n. \\ Figs. 1-14}

Description (based on 7 specimens): Proteocephalidae, Proteocephalinae. Medium-sized to large worms 63-380 mm long $(\mathrm{n}=4)$, up to $1.78 \mathrm{~mm}$ wide. Strobila 

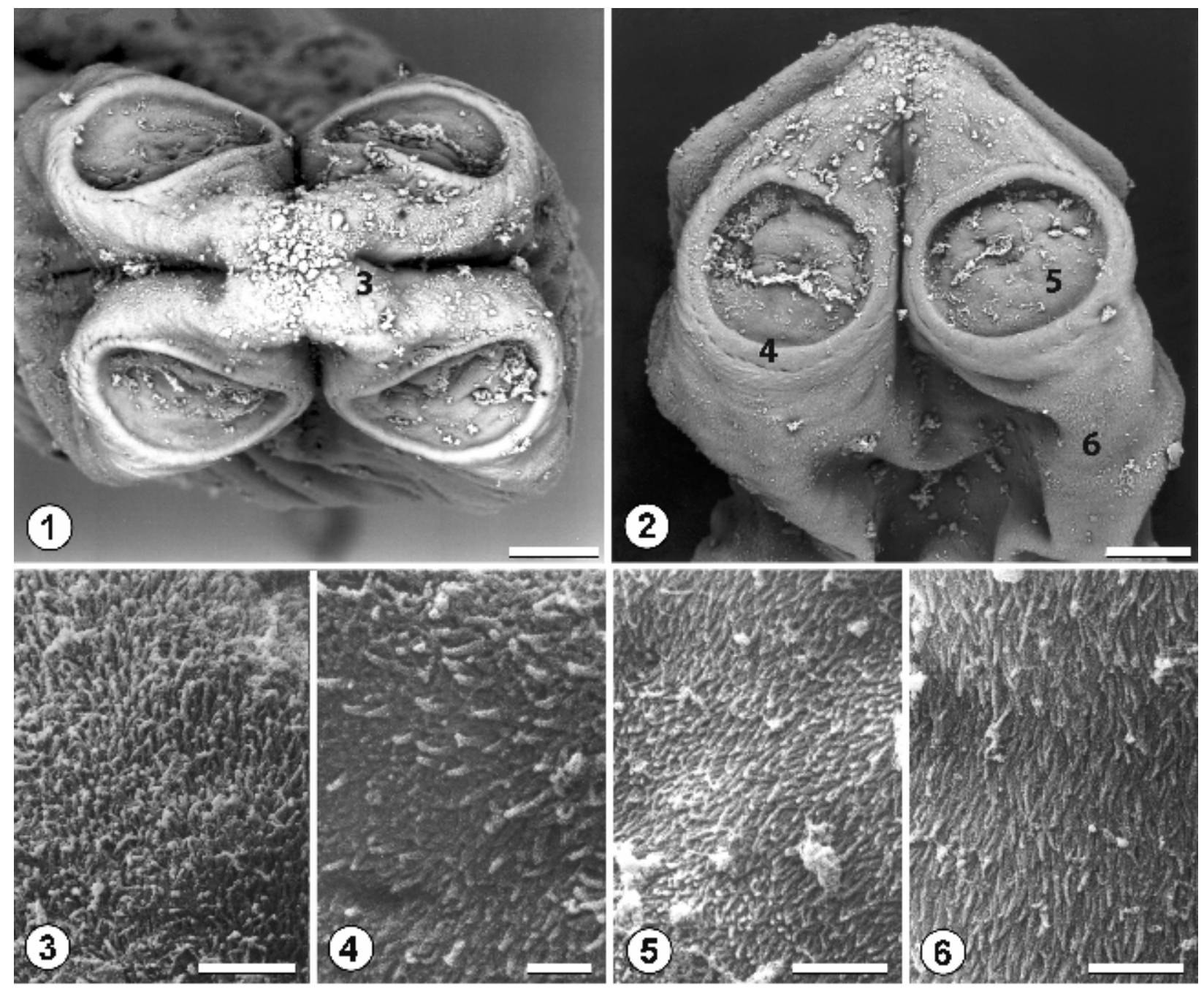

Figs. 1-6. Ophiotaenia bonneti sp. n. Scanning electron micrographs of the scolex, MHNG INVE 37251. Fig. 1. Scolex, apical view. Fig. 2. Scolex, lateral view. Fig. 3. Filiform and blade-like spiniform microtriches on the apex. Fig. 4. Detail of blade-like spiniform microtriches on the marginal surface of the suckers. Fig. 5. Blade-like spiniform microtriches on the surface of the suckers. Fig. 6. Blade-like spiniform microtriches on the surface of the neck. Figs. 1, 2: numbers 3-6 mark the areas shown at higher magnification in Figs. 3-6, respectively. Scale bars: Figs. 1, $2=50 \mu \mathrm{m}$; Figs. 3, 5, $6=5 \mu \mathrm{m}$; Fig. $4=2 \mu \mathrm{m}$.

acraspedote. Scolex small, slightly wider than proliferation zone, $280-385(\times=315, \mathrm{n}=4, \mathrm{CV}=15 \%)$ wide (Figs. 1, 2, 7), without apical organ, but with concentration of cells of granular content (glandular?) below apex and at level of suckers (Figs. 7, 8). Suckers uniloculate, circular, four in number, $130-180(\times=154, \mathrm{n}=16, \mathrm{CV}$ $=11 \%$ ) in diameter. Sucker diameter $50-52 \%$ of scolex diameter. Tegument characterized by presence of filiform and small blade-like microtriches on apex (Fig. 3), slightly larger on marginal surface of suckers (Fig. 4), on internal surface of suckers (Fig. 5), and on anterior region of proliferation zone (Fig. 6).

Strobila consisting of $122-239(n=4)$ proglottides: 90-117 immature proglottides (up to appearance of spermatozoa in vas deferens), 4-12 mature proglottides (up to appearance of eggs in uterus), 11-42 pregravid proglottides (up to appearance of hooks in oncospheres) and 15-71 gravid proglottides.
Immature, mature and pregravid proglottides wider than long to longer than wide (length to width ratio 1:0.42-1.44) (Figs. 9, 10); gravid proglottides usually longer than wide (length to width ratio 1:0.91-2.48) (Fig. 11). Tegument thick. Internal longitudinal musculature developed, forming anastomosed bundles of muscles (Fig. 14). Sub-tegumental musculature developed. Ventral osmoregulatory canals 6-11 in diameter, dorsal osmoregulatory canals 4-9 in diameter, situated medially between $13-26 \%$ of lateral margin of proglottis, dorsal one often more medial than ventral (Figs. 9, 10).

Testes medullary, 100-177 $(\times=134, \mathrm{n}=37, \mathrm{CV}=$ $15 \%$ ) in number, in two lateral fields, in one layer, longitudinally overlapped by osmoregulatory canals (Figs. $9,10)$. Testes round to ovoid, 50-75 in diameter, usually reaching vitelline follicles in immature and mature proglottides, but not reaching posteriorly to ovary (Figs. $9,10)$. Genital atrium present. Genital pores irregularly 


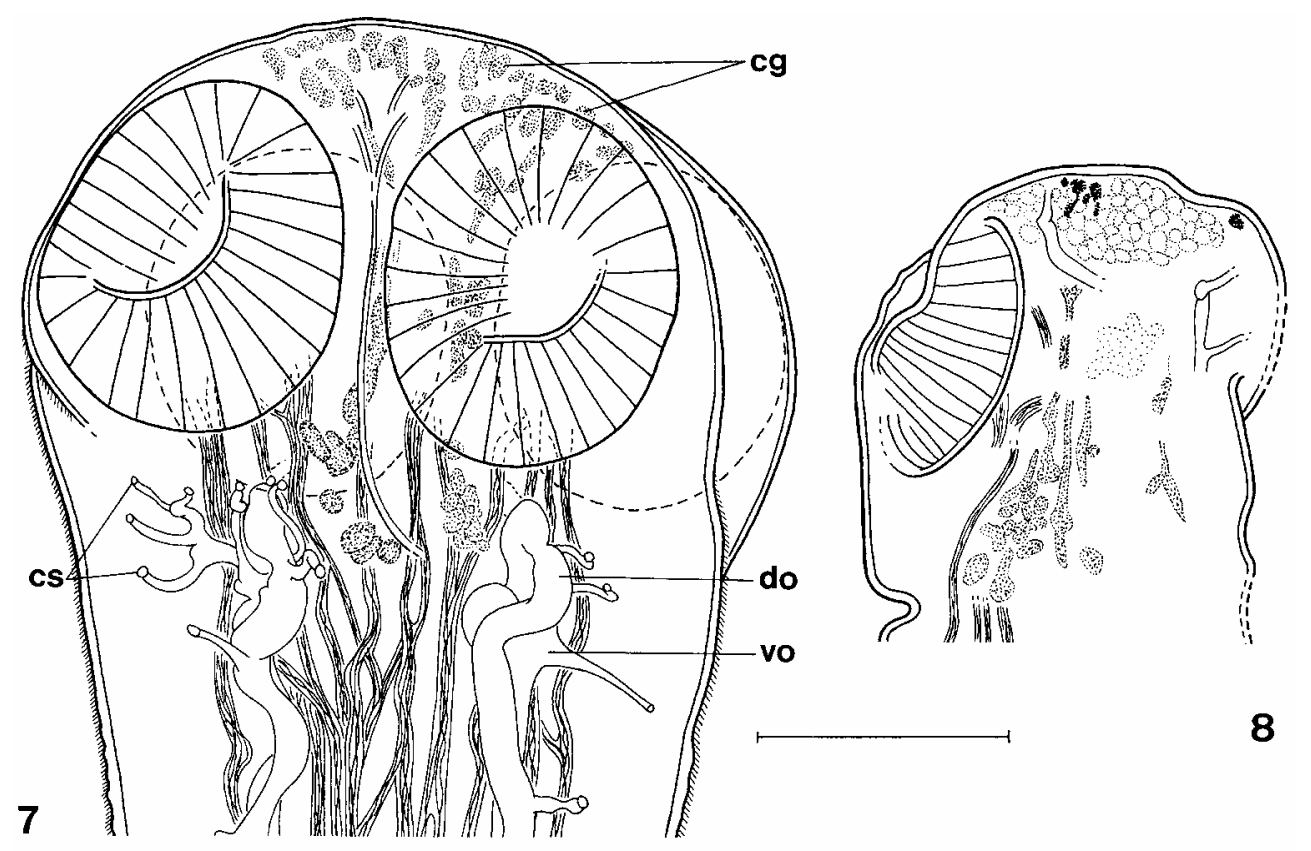

Figs. 7, 8. Ophiotaenia bonneti sp. n. Line drawings of the scolex. Fig. 7. Holotype, dorsal view, MHNG INVE 37237, showing the osmoregulatory canals with numerous secondary canals directed towards the surface. Fig. 8. Paratype, frontal view, IPCAS C-400. Abbreviations: cg - cells with finely granular cytoplasm; cs - secondary canals ending beneath the tegument; do - dorsal osmoregulatory canal; vo - ventral osmoregulatory canal. Scale bars: Figs. 7, $8=100 \mu \mathrm{m}$.

alternate, situated anteriorly, $\mathrm{PP}=15-29 \%(\times=21 \%, \mathrm{n}$ $=41, \mathrm{CV}=18 \%$ ) (Figs. 9, 11).

Cirrus pouch pyriform, thin-walled, 119-323 long $(\times$ $=208, \mathrm{n}=44, \mathrm{CV}=30 \%$ ) (Figs. 9, 11), $\mathrm{PC}=15-24 \%$ $(\times=19 \%, n=44, C V=12 \%)$ (Fig. 10). Cirrus occupying up to $65 \%$ of cirrus pouch length. Genital ducts passing between osmoregulatory canals. Ejaculatory duct coiled. Vas deferens coiled, occupying rounded field extending between proximal part of cirrus pouch and median part of uterus, not crossing midline of proglottis in mature and gravid proglottides (Figs. 9, 10), slightly anterior to base of cirrus pouch.

Vagina anterior $(n=375)$ to cirrus pouch, vaginal sphincter not observed (Figs. 9, 11). Ovary medullary, bilobed in dorso-ventral view and in cross-section, with some dorsal and ventral outgrowths in its marginal part (Figs. 9, 10), OV $=70-83 \%(\times=75 \%, \mathrm{n}=44, \mathrm{CV}=$ $4 \%)$.

Vitelline follicles medullary, arranged in two lateral rows, slightly more numerous posteriorly, occupying $78 \%$ to $90 \%$ of proglottis length, somewhat interrupted at level of cirrus pouch, with 2-3 follicles dorsally and ventrally on each side (Figs. 9, 11).

Uterus medullary, visible in immature proglottides, with development of type 2 (see de Chambrier et al. 2004b) defined as follows: In immature proglottides, concentration of numerous intensely-staining cells, on either side of uterine stem, sometimes difficult to observe, occupying up to $30 \%$ of proglottis width. Lumen present in uterine stem in last immature proglottides. In premature proglottides, uterine stem develops dense lateral elongated digitations, ramified or not. In mature proglottides, gradual appearance and extension of lumen from base to apex into each digitate diverticula; apex constituted by numerous chromophilic cells. Uterus growing in medullary parenchyma, transversally in diverticula, with lumen present in first mature proglottides. Gravid uterus with ramified diverticula on each side, comprising numerous chromophilic cells, occupying most of gravid proglottis width (Fig. 11). Uterus with 18-32 ramified lateral branches on each side occupying up to $93 \%$ of gravid proglottis width (Fig. 11). Eggs shed through a ventral longitudinal split along entire length of proglottis.

Eggs spherical, with hyaline outer envelope, about 50-70 in diameter; embryophore thick, $25-30$ in diameter, consisting of two layers; outer layer thicker than inner nuclei-containing envelope; oncosphere spherical to oval, 11-14 in diameter, with 6 hooklets 6-7 long (Figs. 12, 13).

$\mathrm{T}$ y $\mathrm{p}$ e $\mathrm{h}$ o s t : Rana vaillanti Brocchi, 1877 (Anura, Ranidae).

T y p e 1 o c a 1 i t y : San Gerardo, Guanacaste Province, Costa Rica, 22.05.2002, (1052'50”'N, 85'25'31'” W).

$\mathrm{S}$ i t e : Intestine.

Prevale n c e : $22 \%$ (33 of 147 ).

T y p e m a t e r i a 1: Holotype MHNG, INVE 37237: 02PARA-472.02, San Gerardo, Guanacaste Province, Costa 

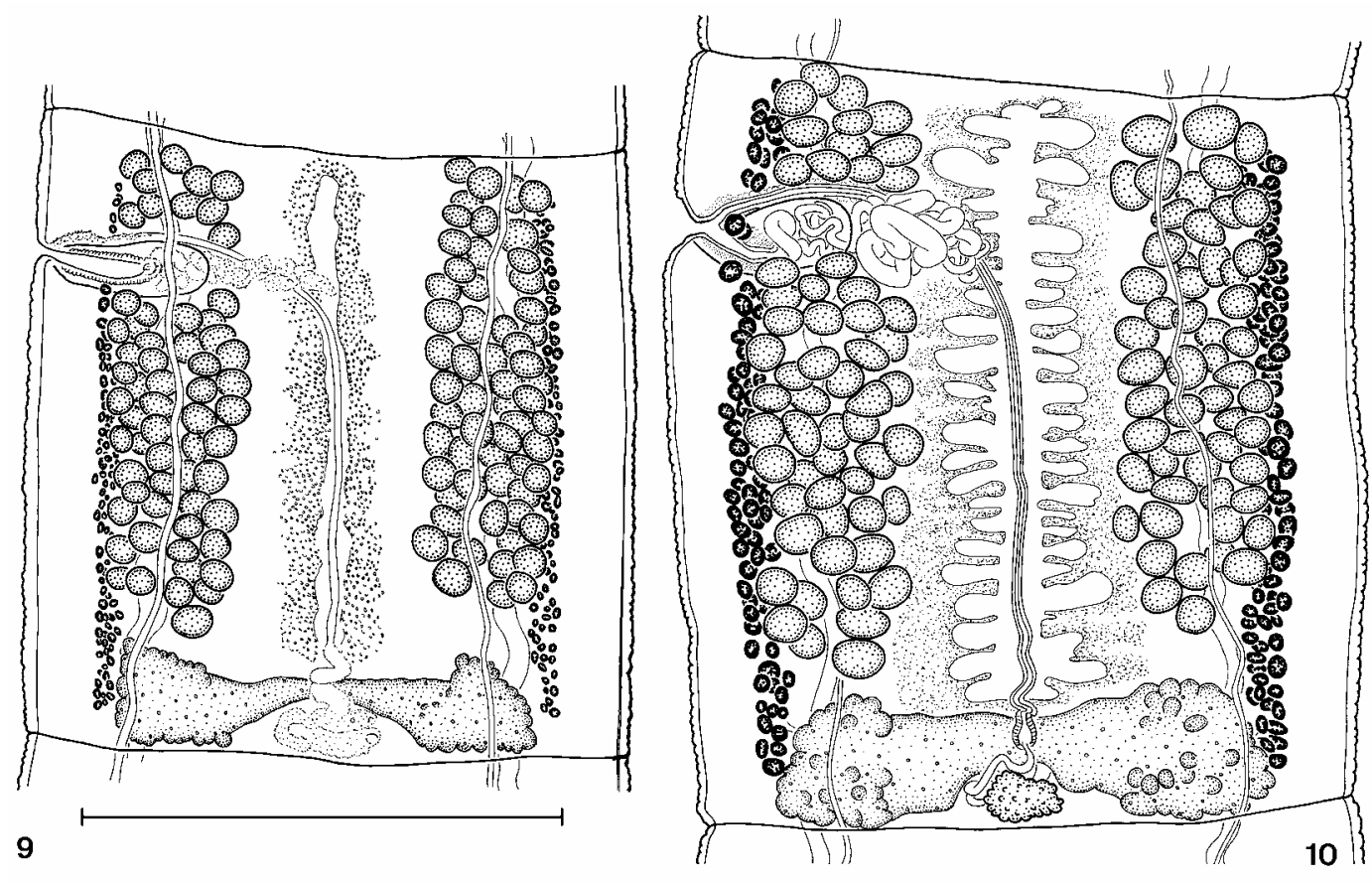

Figs. 9, 10. Ophiotaenia bonneti sp. n. Line drawings of proglottides. Holotype, MHNG INVE 37237. Fig. 9. Dorsal view of an immature proglottis. Fig. 10. Dorsal view of a mature proglottis. Scale bars: Figs. 9, $10=500 \mu \mathrm{m}$.

Rica $\left(10^{\circ} 52^{\prime} 50^{\prime \prime} \mathrm{N}, 85^{\circ} 25^{\prime} 31^{\prime \prime} \mathrm{W}\right), 22.05 .2002 ; 1$ paratype MHNG, INVE 37238: 02-PARA-467.01, Río Pizote between Brasilia and Dos Rios, Guanacaste Province, Costa Rica, (1056'24”N, 85²4’46”'W), 22.05.2002; 1 paratype MHNG, INVE 37239: cross-section series, remaining specimen whole-mounted, 01-PARA-367.03, Buenos Aires, Guanacaste Province, Costa Rica, 23.06.2001; 1 paratype IPCAS C-400: cross section series, remaining specimen whole-mounted), 01-PARA-368.03 A, Buenos Aires, Guanacaste Province, Costa Rica, 23.06.2001; 1 paratype (without scolex) USNPC 97297: 01-PARA-368.03 C, Buenos Aires, Guanacaste Province, Costa Rica, 23.06.2001; 1 paratype MHNG, INVE 37240 (SEM): whole-mount, 99PARA-103, Río Pizote, Guanacaste Province, Costa Rica, 13.06.1999; 1 paratype MHNG, INVE 37241: wholemount, 00-PARA-17, Río Pizote, Guanacaste Province, Costa Rica, 06.07.2000.

V o u c h e r m a t e r i a 1: 1 voucher MHNG, INVE 37251 (SEM): whole-mount, 01-PARA-368.03, Buenos Aires, Guanacaste Province, Costa Rica, 23.06.2001; 1 voucher MHNG, INVE 37247 (SEM): whole-mount, 02-PARA450.3, Río Pizote, Guanacaste Province, Costa Rica, 21.05.2002.

Ophiotaenia s p., i m mature specimens: 1 voucher MHNG, INVE 37248: 99-PARA-104, San Gerardo, Guanacaste Province, Costa Rica, 13.09.1999; MHNG, INVE 37249: whole-mount, 02-438-2, Buenos Aires, Guanacaste Province, Costa Rica, 20.05.2002; MHNG, INVE 37250: in alcohol, 02-448-1, Río Pizote, Guanacaste Province, Costa Rica, 21.05.2002.

E t y m o 1 o g y : The species has been named after Nicolas Bonnet (Satigny, Geneva), famous Geneva winemaker, for his enthusiasm in sharing his outstanding knowledge in oenology.

\section{DISCUSSION}

The new species belongs to the genus Ophiotaenia because of the medullary distribution of gonads as well as the presence of four simple unilocular suckers and two testis fields (Freze 1965, Schmidt 1986). According to Brooks (1978a), Schmidt (1986) and Rego (1994), Batrachotaenia is considered as junior synonym of Ophiotaenia. Schmidt (1986) did not list three species which need to be transferred to Ophiotaenia: Batrachotaenia ceratophryos becomes Ophiotaenia ceratophryos (Parodi et Widakowich, 1916) comb. n., B. tigrina becomes $O$. tigrina (Woodland, 1925) comb. n., and $B$. hernandezi (Flores-Barroeta, 1955) becomes O. hernandezi (Flores-Barroeta, 1955) comb. $\mathrm{n}$.

Of the approximately 74 species of Ophiotaenia currently recognized parasitizing reptiles and amphibians (Schmidt 1986), 23 species parasitize amphibians (Table 1): Ophiotaenia alternans Riser, 1942; O. amphiumae Zeliff, 1932; O. bonariensis Szidat et Soria, 1954; O. bufonis Vigueras, 1942 (redescribed by Freze and Ryšavý, 1976, from Bufo taladai); O. calamensis Puga et Formas, 2005; O. carpathica (Sharpilo, Kornyushin et Lisitsina, 1979); O. ceratophryos (Parodi et Widakowich, 1916); O. cryptobranchi La Rue, 1914; O. ecuadorensis Dyer, 1986; O. filaroides (La Rue, 1909); $O$. gracilis Jones, Cheng et Gillespie, 1958; O. hernandezi (Flores-Barroeta, 1955); O. junglensis Srivastava et Capoor, 1980; O. hylae Johnston, 1912 (redescribed by de Chambrier 2004); O. loennbergii (Fuhrmann, 1895); $O$. magna Hannum, 1925; O. noei Wolffhügel, 1948; $O$. olor (Ingles, 1936); O. olseni Dyer et Altig, 1977; O. ranae Yamaguti, 1938; O. saphena Osler, 1931; 

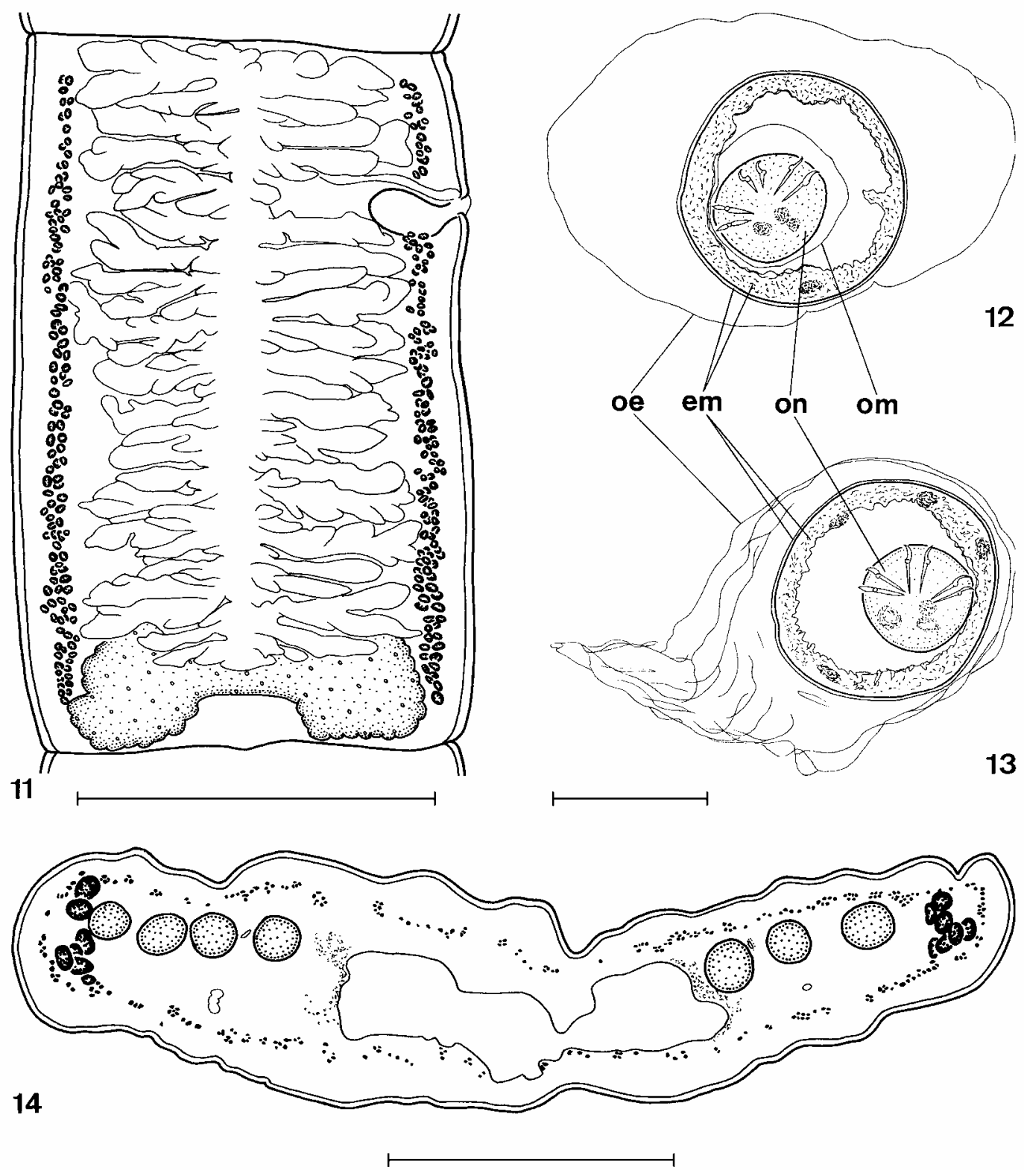

Figs. 11-14. Ophiotaenia bonneti sp. n. Line drawings. Fig. 11. Holotype, dorsal view of a gravid proglottis (diagrammatic), MHNG INVE 37237. Fig. 12. Holotype, egg in distilled water, MHNG INVE 37237. Fig. 13. Paratype, egg in distilled water, INVE 37238. Fig. 14. Paratype, cross-section of mature proglottis at the level of the ovary, MHNG INVE 37239. Abbreviations: em - embryophore; oe - outer envelope; om - oncospheral membrane; on - oncosphere. Scale bars: Figs. 11, $14=500 \mu \mathrm{m}$; Figs. $12,13=50 \mu \mathrm{m}$.

O. schultzei (Hungerbühler, 1910); O. tigrina (Woodland, 1925) (redescribed by Gupta and Arora 1979).

Ophiotaenia bonneti is compared to the 23 species of the Ophiotaenia recorded from amphibians (Fuhrmann 1895, La Rue 1909, 1914a, b, Hungerbühler 1910, Parodi and Widakowich 1916, Hannum 1925, Woodland 1925, Osler 1931, Zeliff 1932, Ingles 1936, Yamaguti 1938, Riser 1942, Vigueras 1942, Wolffhügel 1948, Szidat and Soria 1954, Flores-Barroeta 1955, Jones et al. 1958, Dyer and Altig 1977, Gupta and Arora 1979, Sharpilo et al. 1979, Srivastava and Capoor 1980, Dyer 1986, Puga and Formas 2005). All these species differ from $O$. bonneti by one or several characters: $O$. bonariensis, O. ecuadorensis, $O$. filaroides, O. hylae, $O$. saphena and $O$. tigrina possess an apical organ, while an apical organ is absent in $O$. bonneti; O. cryptobran$c h i$ has a posterior position of the vagina; $O$. loennbergii possesses anterior and posterior position of the vagina, while the position of the vagina in $O$. bonneti is anterior; $O$. calamensis, $O$. ceratophryos and $O$. olseni possess a greater $\mathrm{PC}$ than $O$. bonneti; $O$. alternans shows the presence of a vestigial fifth sucker and the tapered shape of the egg's outer envelope, while $O$. bonneti does not show these features; $O$. bonneti has fewer uter- 
ine diverticula than $O$. amphiumae; the sucker diameter in $\%$ of scolex diameter in O. bonneti is $50-52 \%$, while it is $26-32 \%$ in $O$. ceratophryos, $30-32 \%$ in $O$. gracilis and $66 \%$ in $O$. loennbergii; eggs of $O$. gracilis have a funnel-like depression and embryophore closely investing the oncosphere, while $O$. bonneti does not show these features; $O$. magna and $O$. olor possess a lateral position of the osmoregulatory canals, while the osmoregulatory canals overlap the testis field in $O$. bonneti; $O$. bonneti differs from $O$. noei by a lower number of testes and from $O$. hernandezi and $O$. schultzei by a greater number of testes; $O$. bonneti differs in the more anterior position of the genital pore $(15-29 \%)$ from $O$. bufonis $(50 \%)$, O. carpathica $(54-55 \%)$, O. ceratophryos (39\%), O. ecuadorensis (42-44\%), O. hylae (44-55\%), O. noei (39\%), O. olseni (59\%) and $O$. schultzei (48\%). Finally, O. ranae differs in the paramuscular position of vitelline follicles (see definition in de Chambrier 1990), while O. bonneti possesses vitelline follicles entirely medullary. Ophiotaenia junglensis (Srivastava et Capoor, 1980) is considered a species inquirenda, complying with Art. 67.2.5. of the International Code of Zoological Nomenclature (1999), as the characters that purported to differentiate the taxon were doubtfully defined.

Rudin (1917) erected the genus Batrachotaenia to accommodate four species of proteocephalideans inhabiting anurans. Freze (1965) followed the opinion of Rudin (1917), confirmed the validity of the genus, and transferred 13 species to Batrachotaenia, stressing the following morphological features: (i) scolex and neck always without spines; (ii) mature (and even gravid) proglottides subquadrate or slightly longer than broad; (iii) internal musculature layer extremely weak or absent; (iv) Mehlis' gland large. Brooks (1978a) argued that the subdivision of Ophiotaenia proposed by Freze (1965), which was based on definitive host type, did not constitute natural groups. He also pointed out that Freze's diagnosis of Batrachotaenia, Testudotaenia Freze, 1965 and Ophiotaenia, did not fit all the species Freze placed in these genera (Freze 1965). Brooks (1978a) considered Batrachotaenia and Testudotaenia as junior synonyms of Ophiotaenia. He also discussed the status of Ophiotaenia, which, according to Freze (1965), differs from Proteocephalus in having a preformed uterus and parasitism in reptiles, and considered Ophiotaenia as a junior synonym of Proteocephalus. However, in a phylogenetic analyses of the order Proteocephalidea, de Chambrier et al. (2004) evaluated the structure of the clade Proteocephalus and showed that Proteocephalus species are fundamentally parasites of Palaearctic fishes. Pending a complete revision of the group, they defined an aggregate (see Article 6B of the International Code of Zoological Nomenclature 1999) for the Palaearctic Proteocephalus, while the affinities of the remaining eight Nearctic and Neotropical Proteocephalus species remained unsatisfactorily resolved (see de Chambrier et al. 2004, p. 162, fig. 1). They suggested that those Proteocephalus species should be formally removed from the genus after their evolutionary relationships are better known. With such a redefinition of the genus Proteocephalus, it would only cause more confusion if we place our new species in this genus, even provisionally.

A similar situation prevails in the structure of the clade Ophiotaenia (see de Chambrier et al. 2004, fig. 1): a monophyletic group of species harbouring the uterus of the type 1 is found in the Elapidae and Viperidae whereas others species with the uterus of the type 2 (see de Chambrier et al. 2004 for definition) are dispersed in different clades. No Ophiotaenia species parasitizing amphibians was included in that study, however, we know that both types of uterine development occur in Ophiotaenia from amphibians, i.e. the type 1 in $O$. bufonis (Freze and Ryšavý 1976, p. 103, fig. 6), O. bonariensis (Szidat and Soria 1954, fig. 9b, c); the type 2 in $O$. filaroides (La Rue 1909, figs. 30, 31) and O. bonneti (Fig. 9, present paper). This may be an indication that proteocephalideans of amphibians are not monophyletic. Until more information is available, we conservatively choose to keep all of them in Ophiotaenia, regardless of definitive host type.

The prevalence of the Proteocephalidea is usually very low in amphibians, at least in the Neotropical region (Table 2). In Ecuador, only 9 (all anurans) of 2,200 (0.41\%) amphibians representing 91 species (90 anurans and 1 caudatan) studied between 1983 and 1990 were infected with proteocephalidean cestodes: four Hyla geographica Spix, 1824, two Hyla boans (Linnaeus, 1758), one Osteocephalus taurinus Steindachner, 1862, one Leptodactylus labrosus Jiménez de la Espada, 1875 and one Ceratophrys cornuta (Linnaeus, 1758) - host of Nomimoscolex touzeti de Chambrier et Vaucher, 1992, (Zygobothriinae) (unpublished results, MHNG data base). In Paraguay, only 7 (all anurans) of 1,510 amphibians representing 64 species (all anurans) studied between 1979 and $2002(0.46 \%)$ were infected with proteocephalideans: one Hyla raniceps (Cope, 1862), one H. sanborni Schmidt, 1944, two Pseudis paradoxa (Linnaeus, 1758), two Physalaemus nattereri (Steindachner, 1863) and one Lepidobatrachus sp. (unpublished results, MHNG data base). Similarly, participants in a project coordinated by one of the authors (D. Brooks) have examined 1,008 amphibians representing 47 species (46 anurans and 1 caudatan) in the ACG and have found proteocephalideans only in 33 individuals(3\%). It is important to note, however, that all adult proteocephalideans occurred in Rana vaillanti. Thus, the prevalence of $O$. bonneti is $22 \%(33 / 147 R$. vaillanti examined). We globally observe a very low mean prevalence of the Proteocephalidea in Neotropical amphibians (about $0.41 \%-3 \%$ ), but in the case of some host species, the prevalence can reach up to $25 \%$. We do not consider the prevalence of the two host species, 
Table 1. Ophiotaenia species (currently accepted taxons only) previously known as parasite of amphibian hosts.

\begin{tabular}{|c|c|c|}
\hline Parasite species & Host species & Locality \\
\hline Ophiotaenia alternans & Amphiuma tridactylum Cuvier, 1827 & USA \\
\hline O. amphiumae & Amphiuma tridactylum Cuvier, 1827 & USA \\
\hline O. bonariensis & Leptodactylus ocellatus (Linnaeus, 1758) & Argentina \\
\hline O. bufonis & Bufo peltacephalus Schwartz, 1960 & Cuba \\
\hline O. calamensis & $\begin{array}{l}\text { Telmatobius dankoi Formas, Northland, Capetillo, Nuñez, Cuevas et } \\
\text { Brieva, } 1999\end{array}$ & Chile \\
\hline O. carpathica & Triturus cristatus (Laurenti, 1768) & Ukraine \\
\hline O. ceratophryos & Ceratophrys ornata (Bell, 1843) & Argentina \\
\hline O. cryptobranchi & Cryptobranchus alleganiensis (Daudin, 1803) & USA \\
\hline O. ecuadorensis & Hyla geographica Spix, 1824 & Ecuador \\
\hline O. filaroides & Amblystoma tigrinum Green, 1825 & USA \\
\hline O. gracilis & Rana catesbeiana Shaw, 1802 & USA \\
\hline O. hernandezi & Rana sp. & Mexico \\
\hline O. junglensis & Hoplobatrachus tigerinus (Daudin, 1802) & India \\
\hline O. hylae & Litoria aurea (Lesson, 1829) & Australia \\
\hline O. loennbergii & Necturus maculosus (Rafinesque, 1818) & USA \\
\hline O. magna & Rana catesbeiana Shaw, 1802 & USA \\
\hline O. noei & Caudiverbera caudiverbera (Linnaeus, 1758) & Chile \\
\hline O. olor & Rana aurora Baird et Girard, 1852 & USA \\
\hline O. olseni & Hyla geographica Spix, 1824 & Ecuador \\
\hline O. ranae & Rana nigromaculata Hallowell, 1861 & Japan \\
\hline O. saphena & Rana clamitans Latreille in Sonnini de Manoncourt and Latreille 1801 & USA \\
\hline O. schultzei & Pyxicephalus adspersus Tschudi, 1938 & South Africa \\
\hline O. tigrina & Hoplobatrachus tigerinus (Daudin, 1802) & India \\
\hline
\end{tabular}

Table 2. Proteocephalidean tapeworms collected from amphibian hosts in South American and Central American countries.

\begin{tabular}{|l|l|c|c|c|}
\hline Country/Parasite species & Host & $\begin{array}{c}\text { No. hosts } \\
\text { examined }\end{array}$ & $\begin{array}{c}\text { No. hosts } \\
\text { infected }\end{array}$ & $\begin{array}{c}\text { Prevalence } \\
(\%)\end{array}$ \\
\hline Ecuador & $\mathbf{9 1}$ species & $\mathbf{2 , 2 0 0}$ & $\mathbf{9}$ & $\mathbf{0 . 4 1}$ \\
Ophiotaenia olseni & Hyla geographica & 30 & 1 & 3.3 \\
Ophiotaenia sp. 1 & Hyla geographica & 30 & 3 & 10 \\
Ophiotaenia sp. 2 & Hyla boans & 9 & 2 & 22 \\
Ophiotaenia sp. 3 & Osteocephalus taurinus & 46 & 1 & 2.2 \\
Ophiotaenia sp. 4 & Leptodactylus labrosus & 4 & 1 & 25 \\
Nomimoscolex touzeti de Ch. et Vaucher, 1992 & Ceratophrys cornuta & 1 & 1 & 100 \\
\hline Paraguay & 64 species & $\mathbf{1 , 5 1 0}$ & 7 & $\mathbf{0 . 4 5}$ \\
Ophiotaenia sp. 5 & Hyla raniceps & 100 & 1 & 1 \\
Ophiotaenia sp. 6 & Hyla sanborni & 15 & 1 & 6.6 \\
Ophiotaenia sp. 7 & Pseudis paradoxa & 38 & 2 & 5.2 \\
Ophiotaenia sp. 8 & Physalaemus nattereri & 45 & 2 & 4.4 \\
Ophiotaenia sp. 9 & Lepidobatrachus sp. & 1 & 1 & 100 \\
\hline Costa Rica & 47 species & $\mathbf{1 , 0 0 8}$ & $\mathbf{3 3}$ & $\mathbf{3 . 3}$ \\
O. bonneti & Rana vaillanti & 147 & 33 & 22 \\
\hline
\end{tabular}

Ceratophrys cornuta and Lepidobatrachus sp., collected in only one individual (Table 2). We have to point out that all the Ophiotaenia sp. listed in Table 2 are considered as new species, study of which is in progress. These preliminary studies indicate that each amphibian species listed above (Table 2) hosts a different species of proteocephalidean; therefore, these proteocephalideans all appear to be oixenous (sensu Euzet and Combes 1980).

Acknowledgements. We are grateful to the scientific and technical staff of the ACG for support of this study, in particular: Elda Araya, Roger Blanco, Carolina Cano, María Marta Cha- varría, Felipe Chavarría, Roberto Espinoza, Dunia García, Guillermo Jiménez, Elba López, Sigifredo Marin, Alejandro Masis, Calixto Moraga, Fredy Quesada and Petrona Rios. Thanks also to Dan Janzen and Winnie Hallwachs, scientific advisers to the ACG, for their support. This study was funded by a research grant from the Natural Sciences and Engineering Research Council (NSERC) of Canada to DRB. We also thank David I. Gibson and Eileen Harris (London), for loan of material, Jean Mariaux and the two anonymous referees for fruitful suggestions, Janik Pralong for technical assistance, Gilles Roth for finalising the drawings and Jean Wuest (Geneva) for taking scanning electron micrographs. 


\section{REFERENCES}

BROOKS D.R. 1978a: Systematic status of proteocephalid cestodes from reptiles and amphibians in North America with descriptions of three new species. Proc. Helminthol. Soc. Wash. 45: 1-27.

BROOKS D.R. 1978b: Evolutionary history of the cestode order Proteocephalidea. Syst. Zool. 27: 312-323.

de CHAMBRIER A. 1990: Redescription de Proteocephalus paraguayensis (Rudin, 1917) (Cestoda: Proteocephalidae) parasite de Hydrodynastes gigas (Dum., Bibr. \& Dum., 1854) du Paraguay. Syst. Parasitol. 16: 85-97.

de CHAMBRIER A. 2001: A new tapeworm from the Amazon, Amazotaenia yvettae n. gen., n. sp. (Eucestoda: Proteocephalidea) from the siluriform fishes Brachyplatystoma filamentosum and B. vaillanti (Pimelodidae). Rev. Suisse Zool. 108: 303-316.

de CHAMBRIER A. 2004: Redescription of Ophiotaenia hylae Johnston, 1912 (Eucestoda: Proteocephalidea), parasite of Litoria aurea (Amphibia: Hylidae) from Australia. Rev. Suisse Zool. 111: 371-380.

de CHAMBRIER A., VAUCHER, C. 1992: Nomimoscolex touzeti n. sp. (Cestoda), a parasite of Ceratophrys cornuta (L.): first record of a Monticellidae in an amphibian host. Mem. Inst. Oswaldo Cruz 87 (Suppl. 1): 61-67.

de CHAMBRIER A., ZEHNDER M.P., VAUCHER C., MARIAUX J. 2004: The evolution of the Proteocephalidea (Platyhelminthes, Eucestoda) based on an enlarged molecular phylogeny, with comments on their uterine development. Syst. Parasitol. 57: 159-171.

DYER W.G. 1986: Ophiotaenia ecuadorensis n. sp. (Cestoda: Proteocephalidae) from Hyla geographica Spix, 1824 in Ecuador. J. Parasitol. 72: 599-601.

DYER W.G., ALTIG R. 1977: Ophiotaenia olseni n. sp. (Cestoda: Proteocephalidae) from Hyla geographica Spix, 1824 in Ecuador. J. Parasitol. 63: 790-792.

EUZET L., COMBES C. 1980: Les problèmes de l'espèce chez les animaux parasites. Mem. Soc. Zool. Fr. 40: 239285.

FLORES-BARROETA L. 1955: Cestodos de vertebrados. III. Proteocephalus hernandezi nov. sp., Ophiotaenia nattereri Parona, 1901, Bertiella lopez-neyrai nov. sp. Ciencia 15: 33-38.

FREZE V.I. 1965: Essentials of Cestodology. Vol. V. Proteocephalata in Fish, Amphibians and Reptiles. Publ. House Nauka, Moscow, 538 pp. (Israel Program of Scientific Translation, 1969, Cat. No. 1853, v + 597 pp).

FREZE V.I., RYŠAVÝ B. 1976: Cestodes of the suborder Proteocephalata Spassky, 1957 (Cestoda: Pseudophyllidea) from Cuba and description of new species Ophiotaenia habanensis sp. n. Folia Parasitol. 23: 97-104.

FROST D.R. 2004: Amphibian Species of the World: an Online Reference. Version 3.0 (22 August, 2004). Electronic Database accessible at http://research.amnh.org/ herpetology/amphibia/index.html. American Museum of Natural History, New York, USA.

FUHRMANN O. 1895: Die Tänien der Amphibien. Zool. Jahrb. Abt. Anat. 9: 207-226.

GUPTA N.K., ARORA S. 1979: On Proteocephalus tigrinus Woodland, 1925 (Proteocephaloidea: Proteocephalidae), a cestode parasite of Rana tigrina at Amritsar (Punjab, India). Res. Bull. (Science) Punjab Univ. 30: 79-82.

HANNUM C.A. 1925: A new species of cestode, Ophiotaenia magna $\mathrm{n}$. sp. from the frog. Trans. Am. Microsc. Soc. 64: 148-152.

HOBERG E.P., SIMS D.E., ODENSE P.H. 1995: Comparative morphology of the scolices and microtriches among five species of Tetrabothrius (Eucestoda: Tetrabothriidae). J. Parasitol. 81: 475-481.

HUNGERBÜHLER M. 1910: Studien an Gyrocotyle und Cestoden. Ergebnisse einer von L. Schultze ausgeführten zoologischen Forschungsreise in Südafrika. Jena Denkschr. 16: 495-522.

INGLES L.G. 1936: Worm parasites of California Amphibia. Trans. Am. Microsc. Soc. 55: 73-92.

INTERNATIONAL CODE OF ZOOLOGICAL NOMENCLATURE 1999: Fourth Edition. The International Trust for Zoological Nomenclature, London, xxix $+306 \mathrm{pp}$.

JOHNSTON T.H. 1912: Notes on some Entozoa. Proc. R. Soc. Queensland 24: 63-91.

JONES R.W., CHENG T.C., GILLESPIE R.F. 1958: Ophiotaenia gracilis $\mathrm{n}$. sp., a proteocephalid cestode from a frog. J. Tenn. Acad. Sci. 33: 84-88.

LA RUE G.R. 1909: On the morphology and development of a new cestode of the genus Proteocephalus Weinland. Trans. Am. Microsc. Soc. 28: 17-49.

LA RUE G.R. 1911: A revision of the cestode family Proteocephalidae. Zool. Anz. 38: 473-482.

LA RUE G.R. 1914a: A revision of the cestode family Proteocephalidae. Ill. Biol. Monogr. 1, No. 1-2, pp. 3-351.

LA RUE G.R. 1914b: A new cestode, Ophiotaenia cryptobranchi nov. spec., from Cryptobranchus allegheniensis (Daudin). Rep. Mich. Acad. Sci. 16: 11-17.

OSLER C.P. 1931: A new cestode from Rana clamitans Latr. J. Parasitol. 17: 183-186.

PARODI S.E., WIDAKOWICH V. 1916: Sobre una nueva especie de Taenia. La Prensa Medica Argent. 27: 336-339.

PUGA S., FORMAS R. 2005: Ophiotaenia calamensis, a new species of proteocephalid tapeworm from the Andean aquatic frog Telmatobius dankoi (Leptodactylidae). Proc. Biol. Soc. Wash. 118: 245-250.

REGO A.A. 1994: Order Proteocephalidea Mola, 1928. In: L.F. Khalil, A. Jones and R.A. Bray (Eds.), Keys to the Cestode Parasites of Vertebrates. CAB International, Wallingford, pp. 257-293.

RISER N.W. 1942: A new proteocephalid from Amphiuma tridactylum Cuvier. Trans. Am. Microsc. Soc. 4: 391-397.

RUDIN E. 1917: Die Ichthyotaenien der Reptilien. Rev. Suisse Zool. 25: 179-381.

SCHMIDT G.D. 1986: CRC Handbook of Tapeworm Identification. CRC Press, Boca Raton, Florida, 675 pp.

SCHOLZ T., HANZELOVÁ V. 1998: Tapeworms of the genus Proteocephalus Weinland, 1858 (Cestoda: Proteocephalidae), parasites of fishes in Europe. Studie AV ČR, No. 2/98. Academia, Praha, Czech Republic, 119 pp.

SHARPILO V.P., KORNYUSHIN V.V., LISITSINA O.I. 1979: Batrachotaenia carpathica sp. n. (Cestoda: Ophiotae- 
niidae) a new species of proteocephalid cestodes from amphibians in Europe. Helminthologia 16: 259-264.

SRIVASTAVA A.K., CAPOOR V.N. 1980: On a cyclophyllidean cestode, Batrachotaenia junglensis n. sp. from the intestines of common frog, Rana tigrina from suburban area of Amethi, Sultanpur. Indian J. Parasitol. 3: 39.

SZIDAT L., SORIA M.F. 1954: Cestodes y sus larvas nuevos parasitos de "Leptodactylus ocellatus" (L.) (Amphibia, Leptodactylidae) de la Republica Argentina. Comun. Mus. Argent. Cienc. Nat. "Bernardino Rivadavia" 2: 189-210.

THOMPSON R.C.A., HAYTON A.R., JUE SUE L.P. 1980: An ultrastructural study of the microtriches of adult Proteocephalus tidswelli (Cestoda: Proteocephalidea). Z. Parasitenkd. 64: 95-111.
VIGUERAS P.I. 1942: Proteocephalus bufonis n. sp. (Cestoda), parásito del intestino de Bufo peltacephalus, (Amphibia). Notas Helmintol. No. 5: 208-209, 220-221.

WOLFFHÜGEL K. 1948: Ophiotaenia noei n. sp. (Cestodae). Biologia 5: 15-27.

WOODLAND W.N.F. 1925: On three new proteocephalids (Cestoda) and a revision of the genera of the family. Parasitology 17: 370-394.

YAMAGUTI S. 1938: Studies on the helminth fauna of Japan. Part 22. Two new species of frog cestodes. Jpn. J. Zool. 7: 553-558.

ZELIFF C.C. 1932: A new species of cestode, Crepidobothrium amphiumae, from Amphiuma tridactylum. Proc. U.S. Natl. Mus. 81: 1-3.

Accepted 15 December 2005 